\title{
Succession in harvestman (Opiliones) communities within an abandoned sand quarry in Belgium
}

\author{
Pallieter De Smedt ${ }^{1, *}$ \& Sam Van de Poel $^{2}$ \\ ${ }^{1}$ Ghent University, Forest \& Nature Lab, Geraardsbergsesteenweg 267, B-9090 Gontrode (Melle), Belgium. \\ ${ }^{2}$ Alemstraat 17a, B-1880 Kapelle-op-den-Bos, Belgium. \\ *Corresponding author: Pallieter.desmedt@ugent.be
}

\begin{abstract}
Sand mining strongly alters the existing landscape, transforming an area into a mosaic of native (sand deposits) and foreign soils, strongly influencing biotic development. The method of restoration of such excavated areas is often debated: natural succession or active restoration. We investigated how natural succession shapes harvestman communities, as part of the soil-dwelling community. We sampled harvestmen over a continuous period of 14 months in 25 plots in an abandoned sand quarry in Belgium using pitfall traps. We found significant increases in harvestman activity-density, species richness and diversity with time since abandonment of the various sections of the quarry. After about 15 years, a drastic change in species composition was observed with the establishment of forest species that more strongly depend on humid conditions to complete their life cycle. Colonisation of harvestmen closely followed vegetation succession despite their limited mobility. We argue that natural succession could be a good management tool for restoring harvestman communities as well as those of other soil-dwelling invertebrates in abandoned sand quarries.
\end{abstract}

KEYWORDS. Harvestmen, Restoration, Soil-dwelling fauna, Natural succession, Human-disturbed landscape.

De Smedt P. \& Van de Poel S. 2017. Succession in harvestman (Opiliones) communities within an abandoned sand quarry in Belgium. Belgian Journal of Zooloy 147 (2): 155-169. https://doi.org/10.26496/bjz.2017.13

\section{Introduction}

Inland sand mining leads to radical changes in both biotic and abiotic components of former biotopes. Mining activities often leave an area as a mix of pristine sandy outcrops and sand pits filled with foreign soils. The quarrying company is usually obliged to restore the exploited landscapes to the previously existing situation (often agricultural land) or convert the area into a nature reserve by active restoration measures or via natural succession (PRACH et al. 2011). Although there is an enormous decrease in biodiversity during the quarrying activities, an increase in local biodiversity can appear when the newly formed habitats that have become unique to the region are conserved. These newly formed pristine habitats may contribute considerably to local biodiversity since they can act as refugia for endangered and retreating species that are rare for the region (PRACH et al. 2011; HENEBERG \& ŘEZÁČ 2014). These areas are of key importance in the creation of (temporal) stepping-stones for locally threatened species that require open and nutrient-poor habitats. Management actions in the abandoned sand quarries therefore focus on preserving pristine sites forming a mosaic with areas that are left for natural succession, developing towards forest vegetation in temperate regions (WALKER \& DEL MORAL 2003). 
The development of plant communities on abandoned mine sites has received considerable attention in recent years (PRACH et al. 2013). The development of animal communities, on the contrary, has been poorly investigated. However, the latter can give us useful information on soil development or structural development on the sites under restoration (LAVELLE et al. 2006). Litter-dwelling communities are closely connected to prevailing soil conditions and are strongly bound to litter quality and quantity (THIELE 1977; TOPP et al. 2006). In this respect, certain groups, such as carabid beetles and spiders, are relatively well studied but many other species groups such as harvestmen (Opiliones) are rarely considered. Although their taxonomy is well known, few attempts have been made to study distribution patterns and community composition of harvestmen (CURTIS \& MACHADO 2007). Nevertheless, they can be very numerous in a broad range of different ecosystems and are important at different trophic levels, being a predominantly omnivorous group. They are strongly bound to the soil (e.g., for hunting and egg deposition) and could therefore potentially be used to study soil or, more generally, site development. They are relatively easy to identify, comprise a limited species pool and their communities can be described and compared using simple parameters, such as species composition, species richness and relative species abundance (CURTIS \& MACHADO 2007). We aimed to investigate how harvestman communities develop over time in an abandoned sand quarry, by investigating communities within plots of different durations since abandonment. These plots were therefore at different stages of vegetation succession. Furthermore, it is well known that humidity is one of the key factors determining harvestman distribution (CURTIS \& MACHADO 2007), and humidity increases with vegetation succession. Hence, we hypothesise (1) an increase in harvestman activity-density, species richness and diversity with increasing age of abandonment and (2) that environmental variables related to vegetation succession strongly shape harvestman communities.

\section{Material and Methods}

Study area

The study was carried out in an old sand quarry called "Bos van Aa" located $20 \mathrm{~km}$ north of the city of Brussels, in the municipality of Zemst, Flanders, Belgium. The area is next to the canal Brussel-Schelde connecting the city of Brussels with the river Rupel, a tidal tributary of the River Schelde. Before 1970 the area was characterised as a small scale agricultural landscape (Fig. 1). In the 1970s the area was expropriated for the construction of a large sluice on the canal. Of a total of 220 ha, 110 ha were used to store the superfluous sediment (mostly sand) from these construction works. By the end of the 1970s, sand mining had begun on the area of 110 ha. Towards the end of the nineties, sand quarry activities stopped and most sand pits were filled with non-native soils. These 'fillings' were continued until 2010 when all activities ended. At present, the area is characterised by sandy soils in the centre, while nonnative soil depositions cover the northern and southern parts of the area.

\section{Harvestman collection}

Twenty-five pitfall traps (each $10.5 \mathrm{~cm} \times 10.5 \mathrm{~cm}$, depth $6 \mathrm{~cm}$ ) were placed throughout the area in nine different locations differing in number of years since abandonment (Fig. 2; Table 1). The pitfall traps were operational from $6^{\text {th }}$ of March 2011 until $29^{\text {th }}$ of April 2012. Almost 14 months were covered in order to complete at least a one-year cycle. We are aware that pitfall traps are a composite measure of activity and abundance of organisms (see, e.g., WoODCOCK 2004), and we will therefore talk about "activity-density" instead of abundance. A plastic roof was placed at a height of $5 \mathrm{~cm}$ above every pitfall to prevent litter and larger vertebrates from entering the traps. The traps were filled with a $4 \%$ formaldehyde solution with a drop of detergent to prevent small animals from floating on the surface of the trapping fluid. They were emptied fortnightly from April until September and every four weeks from October until March. Harvestmen were identified using WIJNHOVEN (2009). Harvestman data from all traps were kept separate and no trap data were pooled. It is common practice to pool a few traps 

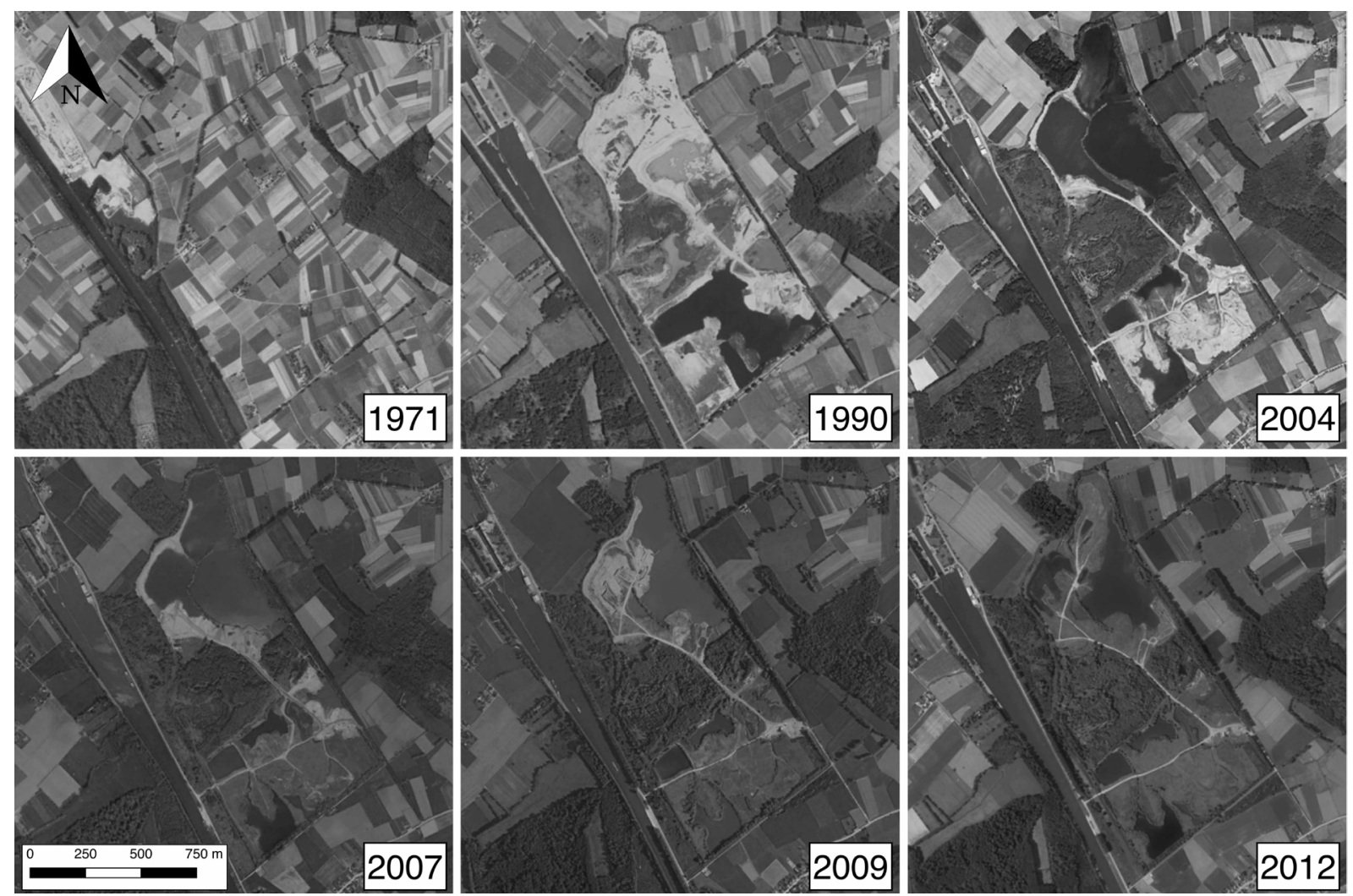

Figure 1 - Evolution of the study area from 1971 to 2012: from a small-scale farming system (1971), to a sand quarry (1980's-2009) ending with a nature reserve (2012). (Source: 1971, '80, 2012 CGeopunt - 2004, 2007, 2009 CGoogle Earth)

per location when using pitfall traps, but we decided not to do this since we wanted to have pointwise harvestman data directly linked to the plant community around each trap (see further).

\section{Environmental data}

Age of abandonment was estimated using aerial pictures and old Google Earth maps dating back to 1990 (www.geopunt.be). Vegetation in a $2 \mathrm{~m} \times 2 \mathrm{~m}$ square around each pitfall trap was sampled using an ordinal Braun-Blanquet cover-abundance scale as modified by BARKMAN et al. (1964) in May 2011. Vegetation communities were grouped and distinguished according to SCHAMINÉE et al. (2010) (Table 1). Ellenberg indicator values for light and moisture were calculated for each plot. In addition, the tree $(>5 \mathrm{~m})$, shrub, herb and litter cover percentages were estimated in the same quadrats. Soil samples were taken around each plot in May 2012 as a composite sample of 30 subsamples to a depth of $10 \mathrm{~cm}$. Organic matter content was estimated after drying the soil at $500{ }^{\circ} \mathrm{C} \cdot \mathrm{pH}-\mathrm{H}_{2} \mathrm{O}$ and the Cation Exchange Capacity were determined to characterise the soil. Soil texture (percentage of sand) was estimated in the field using the "feel method" (THIEN 1979). To get an idea of seasonal differences and local weather conditions we extracted temperature data from a local weather station about $2 \mathrm{~km}$ northwest from the study area (VAN DEN BRANDE 2012).

\section{Data analysis}

All analyses were performed using R version 3.2.2 (R DEVELOPMENT CORE TEAM 2014). Harvestman activity-density, species richness and Shannon diversity according to age of abandonment were tested using linear models (lm-function). We performed hierarchical agglomerative clustering of the harvestman 
communities to distinguish clusters of plots with the pvclust-package (SUZUKI \& SHIMODAIRA 2015). We used a cut-off level of five clusters since we only had 25 plots and used ward 2 as agglomeration method. Lastly a principal component analysis (PCA) was performed using the vegan-package (OKSANEN et al. 2015), with harvestman species activity-density as response variable in order to get a good overview of the importance of different environmental drivers in shaping the harvestman communities.

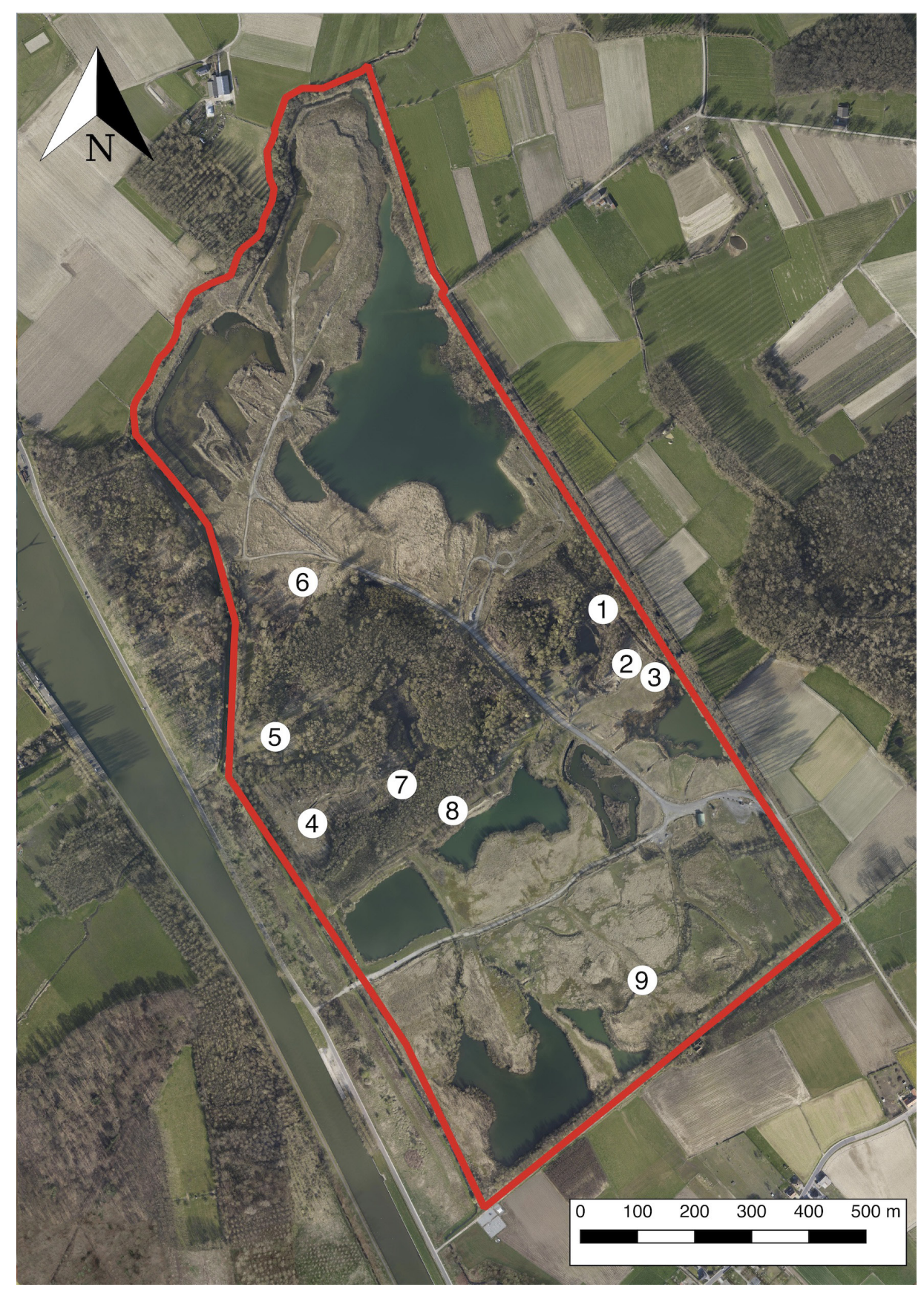

Figure 2 - Overview of the nine sampled locations. 1. OGA (three traps). 2. OGB (two traps). 3. OGC (two traps). 4. WGA (three traps). 5. WGB (three traps). 6. WGC (three traps). 7. M (three traps). 8. OB (three traps). 9. ZV (three traps). The red line represents an area of about 110 ha formerly used as sand quarry. (Source: www.geopunt.be [accessed 5 May 2017]) 


\section{TABLE 1}

Plant communities (according to SCHAMINÉE et al. 2010) of the studied plots with characteristic plant species between brackets. For each plot the years since abandonment, soil origin (foreign or sand originating from the area), sand percentage of soil, $\mathrm{pH}-\mathrm{H}_{2} \mathrm{O}$ and Ellenberg value of moisture is given.

\begin{tabular}{cccccc}
\hline Plot & $\begin{array}{c}\text { Years since } \\
\text { abandonment }\end{array}$ & Soil origin (Foreign/Sand) & \% sand & $\mathbf{p H}$ & Moisture (Ellenberg) \\
\hline \multicolumn{5}{c}{$\begin{array}{c}\text { Disturbed anthropogenic communities } \\
\text { (Agrostis stolonifera, Calamagrostis epigejos) }\end{array}$} \\
OGB1 & 5 & Foreign & 10 & 3.67 & 1.35 \\
WGA2 & 12 & Sand & 80 & 4.57 & 1.57 \\
WGA3 & 12 & Sand & 50 & 3.90 & 1.83 \\
\hline
\end{tabular}

\section{Dry open grasslands on sandy soil}

(Trifolium arvense, Trifolium campestre, Rumex acetosella, Agrostis capillaris, Luzulla campestris, Holcus lanatus)

\begin{tabular}{cccccc} 
OGA1 & 8 & Sand & 80 & 5.66 & 3.32 \\
OGA2 & 12 & Sand & 80 & 5.91 & 3.57 \\
OGA3 & 12 & Sand & 80 & 7.56 & 1.63 \\
OGB2 & 5 & Sand & 65 & 7.70 & 3.74 \\
WGA1 & 12 & Sand & 80 & 5.44 & 3.06 \\
WGB1 & 12 & Sand & 65 & 6.72 & 4.48 \\
WGC1 & 8 & Foreign & 30 & 7.27 & 2.90 \\
OB1 & 22 & Sand & 65 & 7.03 & 2.65 \\
\hline
\end{tabular}

Dry closed grasslands

(Calamagrostis epigejos)

\begin{tabular}{cccccc} 
OGC1 & 5 & Foreign & 65 & 5.69 & 2.68 \\
OGC2 & 5 & Foreign & 65 & 7.01 & 3.22 \\
WGB2 & 12 & Sand & 65 & 6.88 & 3.78 \\
WGC2 & 8 & Foreign & 65 & 7.26 & 3.06 \\
ZV3 & 8 & Foreign & 40 & 6.74 & 4.95 \\
\hline \multicolumn{5}{c}{ Wet closed grasslands } \\
\multicolumn{5}{c}{ (Calamagrostis epigejos) } \\
ZV1 & 8 & Foreign & 30 & 7.26 & \\
ZV2 & 8 & Foreign & 60 & 7.2 & 4.32 \\
\hline
\end{tabular}

Nitrogen rich edges and young forests

(Galium aparine, Glechoma hederaceae, Rubus sp., Ranunculus repens, Betula pendula, Salix cinerea)

\begin{tabular}{cccccc} 
WGB3 & 22 & Sand & 60 & 6.53 & 4.58 \\
WGC3 & 12 & Foreign & 40 & 6.92 & 5.97 \\
M2 & 22 & Sand & 80 & 5.20 & 4.43 \\
OB2 & 22 & Sand & 65 & 5.02 & 3.70 \\
OB3 & 22 & Sand & 65 & 5.19 & 4.07 \\
\hline
\end{tabular}

Wet tall forb community fringing a marsh land

(Phragmites australis, Convolvulus sepium, Eupatorium cannabinum, Symphytum officinale)

\begin{tabular}{cccccc} 
M1 & 17 & Sand & 7 & 5.9 & 6.20 \\
\hline \multicolumn{5}{c}{} & Wet Salix cinerea shrub \\
M3 & 17 & Salix cinerea, Lysimachia vulgaris, Rubus sp., Urtica dioica, Cirsium palustre) \\
& & Sand & 65 & 6.02 & 4.57 \\
\hline
\end{tabular}




\section{Results}

We collected 636 harvestman individuals of which 115 were juveniles that could not be identified to species level with certainty and are excluded from further analysis. The remaining 521 individuals comprised twelve species (38.7\% of the Belgian Harvestmen fauna) (see Appendix 1). The three most abundant species were respectively Trogulus closanicus (135 specimens, 26\%), Nemastoma lugubre (115 specimens, 22\%) and Rilaena triangularis (70 specimens, 13\%). Eight out of twelve species were represented by more than 25 specimens. The number of harvestmen caught within any fourteen day period from any one of the 25 pitfall traps ranged from 2 to 41 specimens. Harvestman activity-density peaked in the first half of June (2011), with a second peak in September-October (2011). A smaller peak was observed in April (2011). No peak in April 2012 was observed, contrasting with the peak of April 2011 (Appendix 2). Possibly this lack of a peak was because spring 2012 was, on average, $5^{\circ} \mathrm{C}$ cooler than spring 2011. However, even in the coldest months, with an average of $3^{\circ} \mathrm{C}$, harvestmen remained active with six specimens caught in contrast to only two specimens caught in the warmest months $\left(25^{\circ} \mathrm{C}\right)$.

Harvestman activity-density $(\mathrm{lm}, \mathrm{t}=5.211, \mathrm{p}<0.001)$ (Fig. $3 \mathrm{a})$, species richness $(\mathrm{lm}, \mathrm{t}=6.270, \mathrm{p}<0.001)$ (Fig. 3b) and Shannon diversity $(\mathrm{lm}, \mathrm{t}=5.230, \mathrm{p}<0.001)$ (Fig. $3 \mathrm{c})$ all strongly increased with increasing age of the plot since abandonment (Fig. 3).
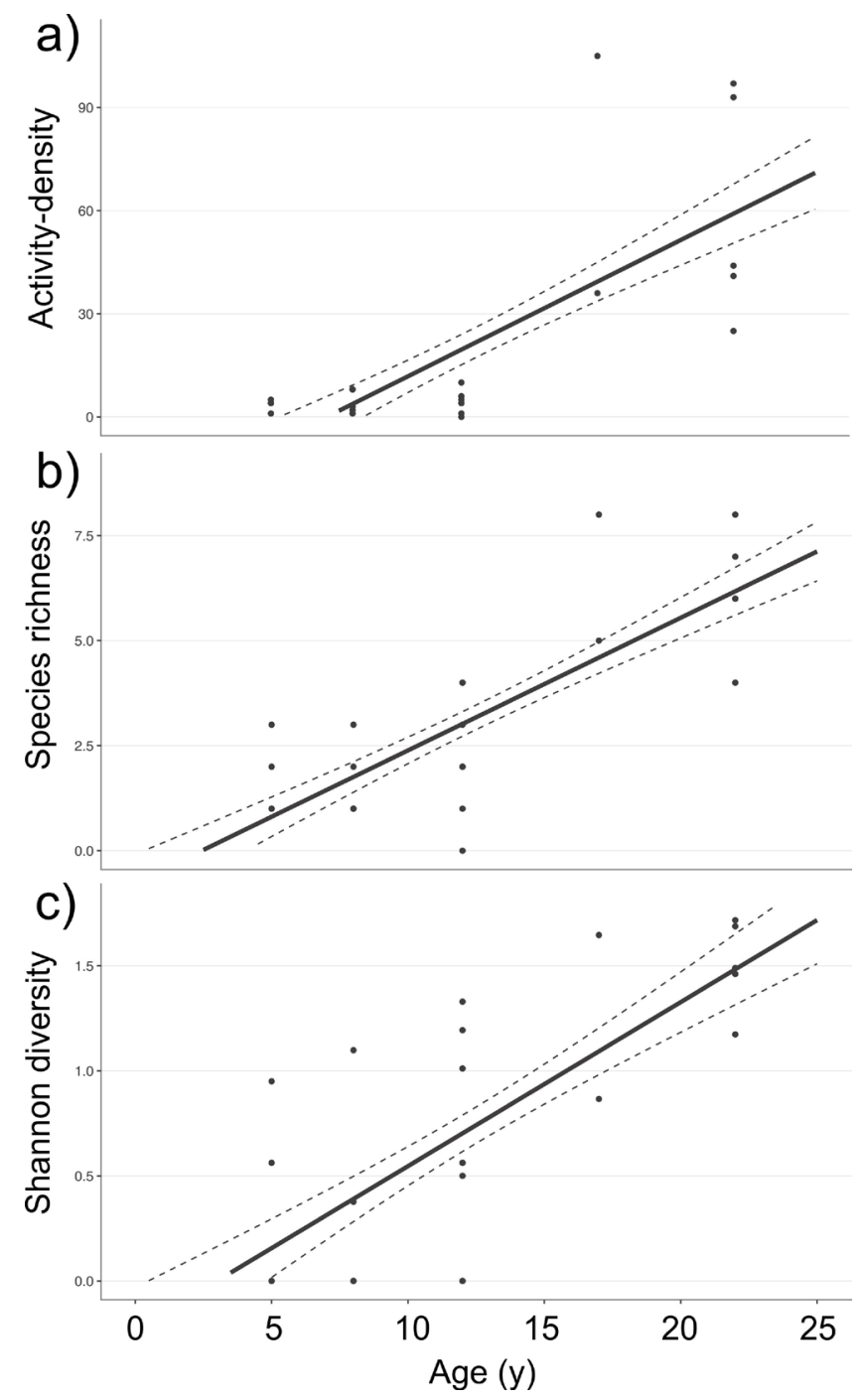

Figure 3 - Harvestman. a. Activity-density. b. Species richness. c. Shannon diversity according to age of abandonment with dots showing the actual data points. Dotted lines denote $\pm 1 *$ standard error. 
TABLE 2

Species activity-density according to the different clusters of plots, together with no. of plots in each cluster, average plot age of the clusters, average harvestman activity-density per cluster and average species richness per cluster. Errors represent $\pm 1 *$ standard deviation.

\begin{tabular}{lccccc}
\hline Cluster & A & B & C & D & E \\
\cline { 2 - 6 } No. of plots & 1 & 2 & 3 & 1 & 17 \\
Average age since abandonment (y) & 17 & $22.0 \pm 0.0$ & $20.3 \pm 2.9$ & 22 & $8.9 \pm 2.9$ \\
\hline Nemastoma lugubre (Müller, 1776) & 41 & $27.0 \pm 5.7$ & $2.3 \pm 3.2$ & 9 & $0.2 \pm 1.0$ \\
Nemastoma bimaculatum (Fabricius, 1775) & 2 & $5.5 \pm 2.1$ & $3.7 \pm 2.1$ & 7 & $0.1 \pm 0.2$ \\
Homalenotus quadridentatus (Cuvier, 1795) & 7 & $9.0 \pm 4.2$ & $6.0 \pm 5.3$ & 4 & $0.4 \pm 0.9$ \\
Trogulus closanicus (Avram, 1971) & 10 & $33.5 \pm 3.5$ & $17.7 \pm 8.1$ & 0 & $0.3 \pm 0.8$ \\
Lacinius ephippiatus (C.L. Koch, 1835) & 25 & $5.5 \pm 4.9$ & 0 & 0 & 0 \\
Oligolophus tridens (C.L. Koch, 1836) & 14 & $5.5 \pm 7.8$ & $0.7 \pm 0.6$ & 0 & $0.1 \pm 0.2$ \\
Rilaena triangularis (Herbst, 1799) & 5 & $8.5 \pm 6.4$ & $4.3 \pm 1.5$ & 18 & $1.0 \pm 1.3$ \\
Mitostoma chrysomelas (Hermann, 1804) & 0 & 0 & 0 & 2 & 0 \\
Phalangium opilio Linnaeus, 1758 & 0 & 0 & 0 & 0 & $2.3 \pm 2.9$ \\
Leiobunum rotundum (Latreille, 1798) & 1 & 0 & $0.3 \pm 0.6$ & 1 & $0.1 \pm 0.2$ \\
Dicranopalpus ramosus (Simon, 1909) & 0 & $0.5 \pm 0.7$ & 0 & 0 & $0.2 \pm 0.4$ \\
Mitopus morio (Fabricius, 1799) & 0 & 0 & 0 & 0 & $0.1 \pm 0.3$ \\
\hline Average activity-density & 105 & $95.0 \pm 2.8$ & $35.0 \pm 9.5$ & 41 & $4.7 \pm 2.7$ \\
Average species richness & 8 & $7.0 \pm 1.4$ & $5.3 \pm 1.5$ & 6 & $2.0 \pm 1.1$ \\
\hline
\end{tabular}

The agglomerative clustering of the different plots according to harvestman communities shows four small clusters ( $\leq 3$ plots each) and one large cluster (17 plots) with very closely related communities (Fig. 4). Cluster (A) consists of the only plot on wet soil that is dominated by willow shrubs, and was abandoned about 17 years ago. Here we found a dominance of the short-legged soil-dwelling species Nemastoma lugubre and a sub-dominance of the long-legged soil species Lacinius ephippiatus and Oligolophus tridens (Table 2). Cluster (B) consists of two young forest plots on drier soils, about 22 years post abandonment. Here the dominant species is the short-legged soil species Trogulus closanicus while Nemastoma lugubre is sub-dominant. A number of other soil species are well represented (Table 2). Cluster A and B strongly differ from all other communities. This is indicated by the large gap between $\mathrm{A}$ and B (at about a height of 40) and the height where all cluster together (about a height of 95) (Fig. 4). The third cluster (C) consists of three different vegetation communities: a community fringing a marshland, a young dry forest and the forest edge bordering a dry open grassland. However, they all have in common their relatively long time since abandonment (>17 years). The dominant species is Trogulus closanicus while other soil species are sub-dominant (Table 2). Cluster (D) again consists of only one community which is a nitrogen-rich edge of a young forest. Here we found a dominance of Rilaena triangularis with a sub-dominance of Nemastoma species (Table 2). The last cluster (E) comprises the largest share of plots. In this cluster, we found almost all grassland plots and only one nitrogen-rich edge plot. They all have in common that they were only abandoned about ten years ago. These plots have low numbers of almost all species (Table 2).

The PCA (Fig. 5) shows the ordination of the plots based on harvestman activity-density data. Plot symbols represent age, separating young plots (max. 12 years old) from older plots (more than 17 years old) along axis 1 (66.45\% variance explained) (Fig. 5a). Species represented with more than 25 
individuals also respond to this axis, with all species having higher activity-densities towards older plots except for Phalangium opilio (Fig. 5b). Most environmental variables are aligned along this axis with increasing tree, herb and litter cover, organic matter content and Ellenberg-value for humidity and decreasing $\mathrm{pH}$ and Ellenberg value for light (Fig. 5c). Axis 2 only explains $10.5 \%$ of the variation and is therefore much less important for harvestman community composition.

\section{Discussion}

We showed that harvestman communities are strongly shaped by years of abandonment in this old sand quarry. Activity-density, species richness and diversity increased with plot age after abandonment. We can clearly distinguish between communities based on age of abandonment and we see a strong switch when plots are older than 15 years.

\section{Harvestmen and age since abandonment}

The number of harvestmen trapped was rather low if we consider the length of the trapping period and the number of pitfall traps. This could possibly be attributed to two reasons; (1) the large share of open habitats on poor soil in our sampling design and (2) the incorporation of a whole year cycle instead of only sampling at peak periods for harvestmen abundance; the latter is the more common practice. Comparing the number of harvestmen per pitfall trap per sampled week in spring/summer, we note comparable numbers in open habitats in the Netherlands (see, e.g., NoORDIJK \& WiJNHOVEN 2009) but much lower numbers compared to forested habitat (see, e.g., NOORDIJK et al. 2012). The large proportion of short-legged soil species in our study can be attributed to the whole year sampling cycle, since many of these species are active as adults across the whole year, compared to long-legged species that are only found as adults during summer (TODD 1949; ADAMS 1984; MUSTER \& MEYER 2014).

The total number of twelve species found in our study area is quite high compared with other mining sites. DUNGER et al. (2001) investigated the harvestman fauna of an abandoned mining site 46 years after afforestation in Eastern Germany and sampled a total of nine species. HENEBERG \& ŘEZÁČ (2014) found only eight species in 28 sand- and gravel-pits in the Czech Republic. The average number of species in the older plots was, however, comparable with our study: five to seven species in afforested plots of 46 years old by DUNGER et al. (2001) and about seven species for plots more than 15 years old by HENEBERG \& ŘEZÁČ (2014). In younger plots (less than 15 years old), HENEBERG \& ŘEZÁČ (2014)

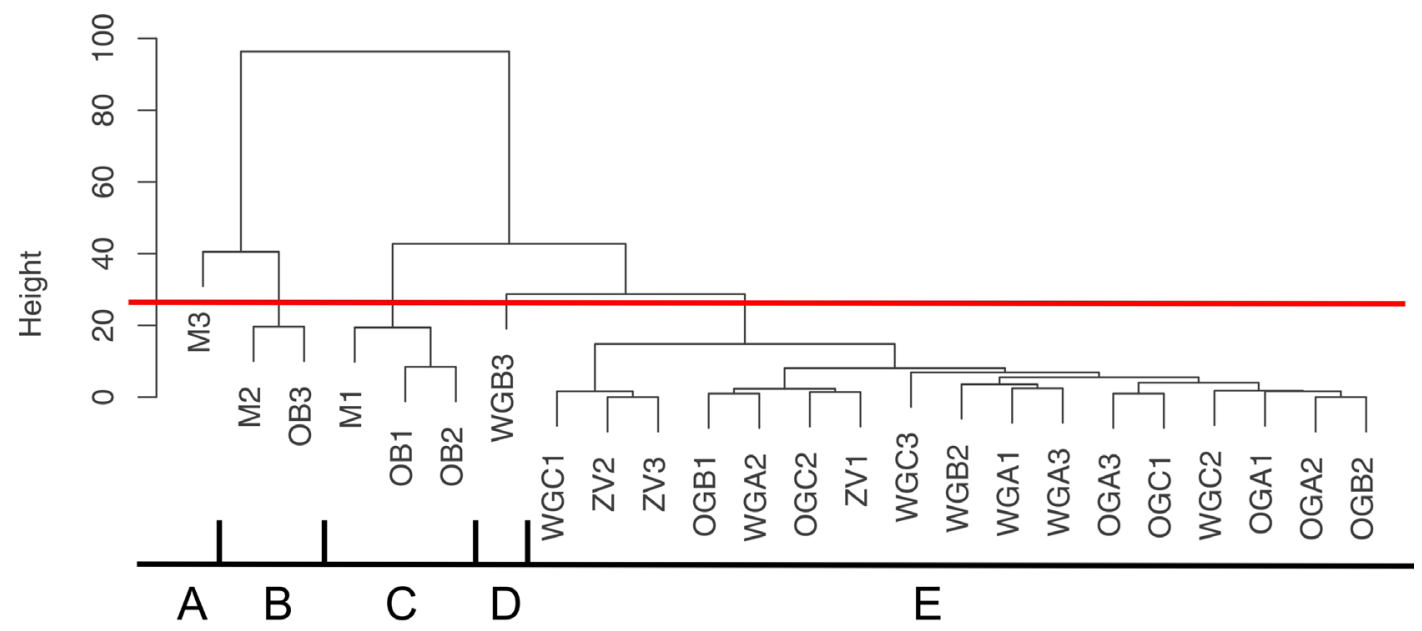

Figure 4 - Hierarchical agglomerative clustering of the plots based on the harvestman communities. The y-axis is a measure of how closely different communities are related to each other. Low values represent very closely-related communities. The red line represents the cut-off point where five clusters are formed indicated by the letters A to E. 
found on average two species in plots younger then five years and five species in plots aging between six and fifteen years. In our study, we found on average less species; zero to four harvestman species in plots between five and twelve years since abandonment. Nevertheless, our multivariate analysis strongly distinguished between plots younger than 12 and older than 17 years so there appears to be a kind of switch in harvestman communities after 15 years of abandonment, a switch that was also documented by HENEBERG \& ŘEZÁČ (2014). This switch is mostly caused by new species entering the community, and already established species increasing their abundance. KUIPER \& NOORDIJK (2012) investigated harvestman fauna in field margins of different age in the Netherlands, and already noted a switch in species abundance after five to six years. Possibly in these more productive systems this switch happens earlier because of the faster vegetation development.
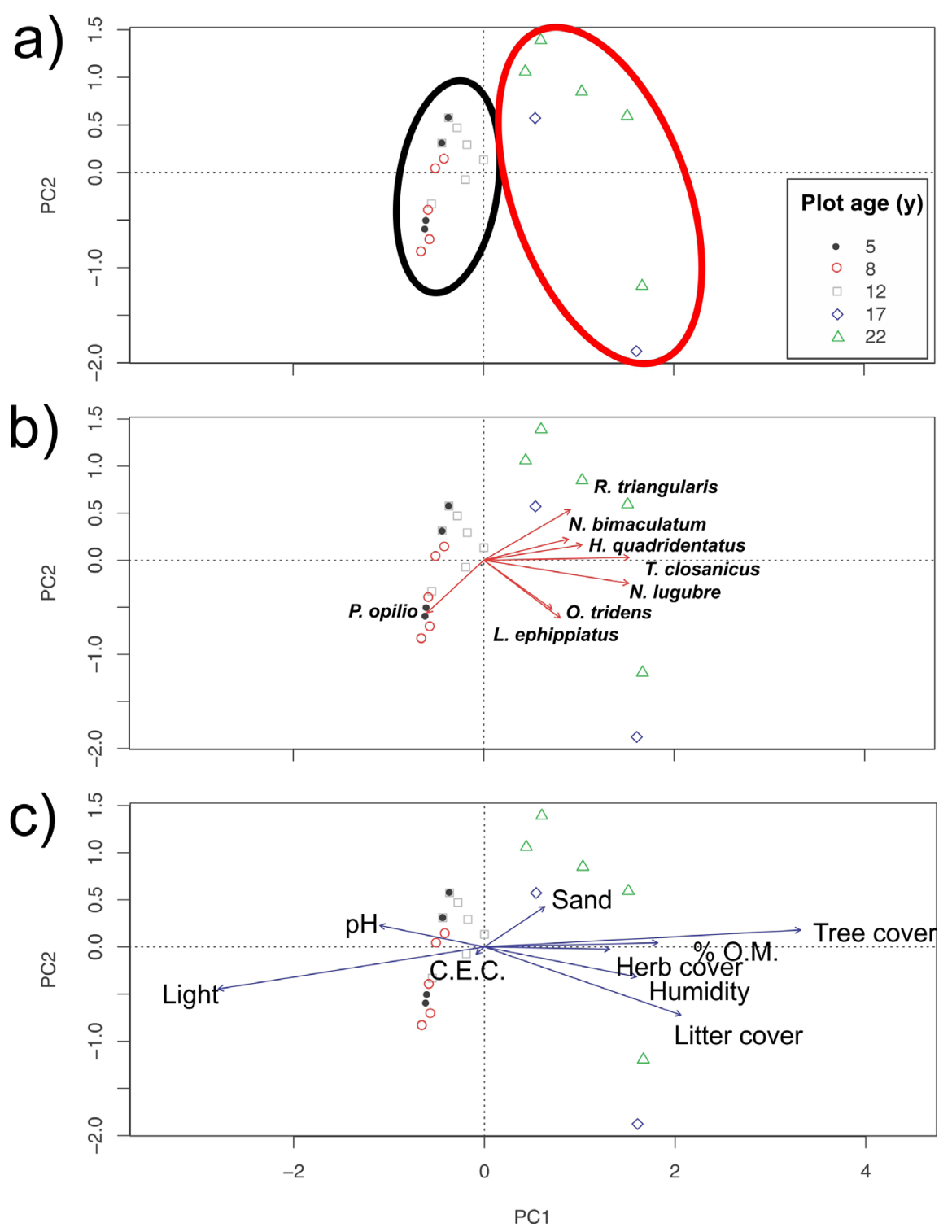

Figure 5 - Multivariate analysis of the plots based on the harvestman species activity-density; symbols represent plot age. a. Clusters plots according to age below (black circle) and above (red circle) 15 years of abandonment, also the explained variance of PCA axes 1 and 2 is presented here. b. Plots and harvestman species with more than 25 individuals. c. Plots and relevant environmental variables. Light and Humidity represent Ellenberg values of the plant communities for, respectively, ambient light and humidity conditions. \% O.M. is the percentage of organic matter content of the mineral soil. 


\section{Vegetation succession}

We were able to link this switch in community composition to vegetation succession. Development of young forests starts at about ten to 15 years, and target woodland is reached after about 25 years on old mining sites (PRACH \& PYŠEK 2001; ŘEHOUNKOVÁ \& PRACH 2008). The higher species richness in forest habitat compared to open habitat is a common finding for harvestmen, with on average 2.8 times more species in forest habitat (CURTIS \& MACHADO 2007). It appears that the time frame for the restoration of plant communities in these areas applies to harvestman communities as well. Harvestman communities with forest species seem to rapidly colonise abandoned plots after a certain degree of vegetation development, despite their limited mobility.

Open habitats that have only recently become abandoned are drier and lack the more humid conditions that are very important for the juveniles and the adults of many species (TODD 1949). The only species in our study that does not require humid conditions and prefers warm and drier conditions is the xerophilous $P$. opilio (WIJNHOVEN 2009). This species was exclusively found in plots of 12 years and younger and ordinated opposite to all other species considered in our multivariate analysis. Also in the UK and the Netherlands, this species is characteristic for thermophilic conditions and open vegetation (TODD 1949; VAN DER HAMMEN 1983; NoORDIJK \& WiJNHOVEN 2009; KUIPER \& NOORDIJK 2012). True soil-dwelling species such as $N$. bimaculatum, $N$. lugubre and T. closanicus are closely aligned with the variables that are related to natural succession: tree cover, herb cover, litter cover, soil organic matter and humidity. These species are ordinated opposite to the arrow representing Ellenberg-values of light, indicating that the species favour more shaded conditions. Most species are also negatively associated with soil $\mathrm{pH}$ but this is probably largely caused by forest development, causing soil $\mathrm{pH}$ to decrease (DE SCHRIJVER et al. 2012). Across all sampled individuals we found T. closanicus to be the most abundant species. Members of the family Trogulidae are specialised snail feeders and rarely dominate harvestman communities (CURTIS \& MACHADO 2007). However, snail abundance is often higher in young forests compared to old forest (STRÖM et al. 2009). This could result in a dominance of this species in younger forests as observed in our study. Its dominance could decline when plots are getting older and snail abundace declines. The second and third most abundant species in our study $(N$. lugubre and $R$. triangularis) are frequently found to be dominant in European harvestman communities (CURTIS \& MACHADO 2007). These species have a wide geographical distribution and occur in a great variety of habitats. The use of pitfall traps causes long-legged species that mainly live in the higher parts of the vegetation, to be relatively underrepresented since they only rarely leave the vegetation layers (ADAMS 1984). Therefore, long-legged species such as P. opilio, L. rotundum, D. ramosus and $M$. morio, which are very common species in Flanders, are probably under-sampled. Adults of these species are less bound to the ground and use higher vegetation layers for foraging, thereby covering a separate ecological niche.

\section{Conclusions}

Harvestman communities are strongly shaped by natural succession in an abandoned sand quarry, resulting in increases in activity-density, species richness and diversity. The increase in diversity has also been found for other soil-dwelling invertebrates in abandoned quarries, such as epigeic beetles, orthopteroids and spiders (HENEBERG \& ŘEZÁČ 2014; HENEBERG et al. 2016). Harvestmen can be added to this list. After about 17 years the harvestman fauna has switched from an open habitat community to a forest community, following vegetation succession. Natural succession is recommended as an effective and cost-efficient management tool for the restoration of litter-dwelling soil fauna in old sand quarries if the development of forest is intended, even for a relatively immobile species group such as harvestmen.

\section{Acknowledgements}

We want to thank all those who conducted the fieldwork with us, especially Eddy De Smedt, Herman Dierickx, Stijn Segers, Johan Van Keer and Kevin Lambeets. We thank the owner Waterwegen en 
Zeekanaal NV, for permission to conduct the research in the area. We also thank Hay Wijnhoven for the verification of a few of the Trogulidae specimens.

\section{References}

ADAMS J. (1984). The habitat and feeding ecology of woodland harvestmen (Opiliones) in England. Oikos, 42: 361-370.

BARKMAN J.J., DoING H. \& SEgal S. (1964). Kritische Bemerkungen und Vorschläge zur quantitativen Vegetationsanalyse. Acta botanica neerlandica, 13: 394-419.

CurTis D.J. \& MACHAdo G. (2007). Ecology. In: Pinto-da-Rocha R. et al. (eds), Harvestmen: the biology of Opiliones: 208-308. Harvard University Press, Cambridge, MA.

De Schrijver A., De Frenne P., Staelens J., Verstraeten G., Muys B., Vesterdal L., Wuyts K., VAN Nevel L., SchelfHout S., De NEVE S. \& VerheYen K. (2012). Tree species traits cause divergence in soil acidification during four decades of postagricultural forest development. Global Change Biology, 18: 1127-1140. https://doi.org/10.1111/j.1365-2486.2011.02572.x

Dunger W., Wanner M., Hauser H., Hohberg K., Schulz H.J., Schwalbe T., Seifert B., Vogel J., VOIGTLÄNDER K., ZimDARS B. \& ZULKA K.P. (2001). Development of soil fauna at mine sites during 46 years after afforestation. Pedobiologia, 45: 243-271. https://doi.org/10.1078/00314050122254957

HENEBERG P. \& ǨEZÁČ M. (2014). Dry sandpits and gravel-sandpits serve as key refuges for endangered epigeic spiders (Araneae) and harvestmen (Opiliones) of Central European steppes aeolian sands. Ecological Engineering, 73: 659-670. https://doi.org/10.1016/j.ecoleng.2014.09.101

Heneberg P., Hesoun P. \& SKUhrovec J. (2016). Succession of arthropods on xerothermophilous habitats formed by sand quarrying: Epigeic beetles (Coleoptera) and orthopteroids (Orthoptera, Dermaptera and Blattodea). Ecological Engineering, 95: 340-356. https://doi.org/10.1016/j.ecoleng.2016.06.022

KUIPER M. \& NOORDIJK J. (2012). Hooiwagens (Opiliones) in Groningse akkerranden. Entomologische berichten, 72: 231-237.

Lavelle P., Decaëns T., Aubert M., Barot S., Blouin M., Bureau F., Margerie P., Mora P. \& Rossi J.-P. (2006). Soil invertebrates and ecosystem services. European Journal of Soil Biology, 42: S3-S15. https://doi.org/10.1016/j.ejsobi.2006.10.002

Muster C. \& Meyer M. (2014). Verbreitungsatlas der Weberknechte des Großherzogtums Luxemburg. Ferrantia 70. Musée national d'Histoire naturelle, Luxembourg.

NoORDIJK J. \& WiJNHOvEN H. (2009). Hooiwagenwaarnemingen uit Zeeuwse akkerranden (Opiliones). Entomologische berichten, 69: 78-82.

NOORDIJK J., LAMMERS M. \& HiJERMAN T. (2012). De strooiselbewonende hooiwagens van stuwwalbossen (Opiliones). Nederlandse faunistische mededelingen, 38: 17-24.

Oksanen J., Blanchet F.G., Kindt R., Legendre P., Minchin P.R., O’Hara R., Simpson G.L., Solymos P., Stevens M. \& Wagner H. (2015). Vegan: Community Ecology Package. R package version 2.0-10.2013. Available from https://cran.r-project.org/web/packages/vegan/index.html [accessed 24 November 2017].

Prach K. \& Pyšek P. (2001). Using spontaneous succession for restoration of human-disturbed habitats: Experience from Central Europe. Ecological Engineering, 17: 55-62.

https://doi.org/10.1016/S0925-8574(00)00132-4

Prach K., Lencová K., Řehounková K., Dvořáková H., Jírová A., Konvalinková P., MudRÁK O., NOVÁK J. \& TRNKOVÁ R. (2013). Spontaneous vegetation succession at different central 
European mining sites: a comparison across seres. Environmental Science and Pollution Research, 20: 7680-7685. https://doi.org/10.1007/s11356-013-1563-7

Prach K., ŘehounKovÁ K., ŘehouneK J. \& KonvalinKovÁ P. (2011). Ecological restoration of central European mining sites: a summary of a multi-site analysis. Landscape Research, 36: 263-268. https://doi.org/10.1080/01426397.2010.547571

R Development Core Team (2014). R: A Language and Environment for Statistical Computing. $\mathrm{R}$ foundation for statistical computing, Vienna.

ŘEHOUNKOVÁ K. \& PRACH K. (2008). Spontaneous vegetation succession in gravel-sand pits: A potential for restoration. Restoration Ecology, 16: 305-312. https://doi.org/10.1111/j.1526-100X.2007.00316.X

Schaminée J.H.J., SÝKORA K.V., Smits N.A.C. \& Horsthuis M.A.P. (2010). Veldgids Plantengemeenschappen van Nederland. KNNV Uitgeverij, Zeist.

Ström L., Hylander K. \& Dynesius M. (2009). Different long-term and short-term responses of land snails to clear-cutting of boreal stream-side forests. Biological Conservation, 142: 1580-1587. https://doi.org/10.1016/j.biocon.2009.02.028

SuZuKi R. \& ShIMOdAIRA H. (2015). Pvclust: Hierarchical clustering with P-values via multiscale bootstrap resampling. R package version 2.0-0. Available from https://cran.r-project.org/web/packages/ pvclust/pvclust.pdf [accessed 5 Dec. 217].

THIELE H.U. (1977). Carabid Beetles in their environments: A study on habitat selection by adaptations in physiology and behaviour. Springer-Verlag, New York.

THIEN S.J. (1979). Aflow diagram for teaching texture-by-feel analysis. Journal of Agronomic Education, 8: $54-55$.

TODD V. (1949). The habits and ecology of the British harvestmen (Arachnida, Opiliones), with special reference to those of the Oxford district. The Journal of Animal Ecology, 18: 209-229. https://doi.org/10.2307/1600

TOPP W., KAPPES H., KUlFAN J. \& ZACH P. (2006). Distribution pattern of woodlice (Isopoda) and millipedes (Diplopoda) in four primeval forests of the Western Carpathians (Central Slovakia). Soil Biology \& Biochemistry, 38: 43-50. https://doi.org/10.1016/j.soilbio.2005.04.012

VAN DEN BRANDE J. (2012). Weather station Kapelle-op-den-Bos. Available from weerstationkapelleopdenbos.be [accessed 22 November 2017].

VAN DER HAMMEN L. (1983). The distribution of spiders and harvestmen (Chelicerata) in the Dutch National Park "De Hoge Veluwe”. Zoölogische Mededelingen, 57: 325-338.

Walker L.R. \& Del Moral R. (2003). Primary Succession and Ecosystem Rehabilitation. Cambridge University Press, Cambridge.

WiJnHOVEN H. (2009). De Nederlandse hooiwagens (Opiliones). Entomologische Tabellen, 3: 1-118.

Woodcock B A (2004). Pitfall trapping in ecological studies. In: Leather S.R. (ed.), Insect Sampling in Forest Ecosystems: 37-57. Methods in Ecology Series, Blackwell Science, Oxford. https://doi.org/10.1002/9780470750513.ch3 
DE SMEDT P. \& VAN DE POEL S., Succession in harvestman communities

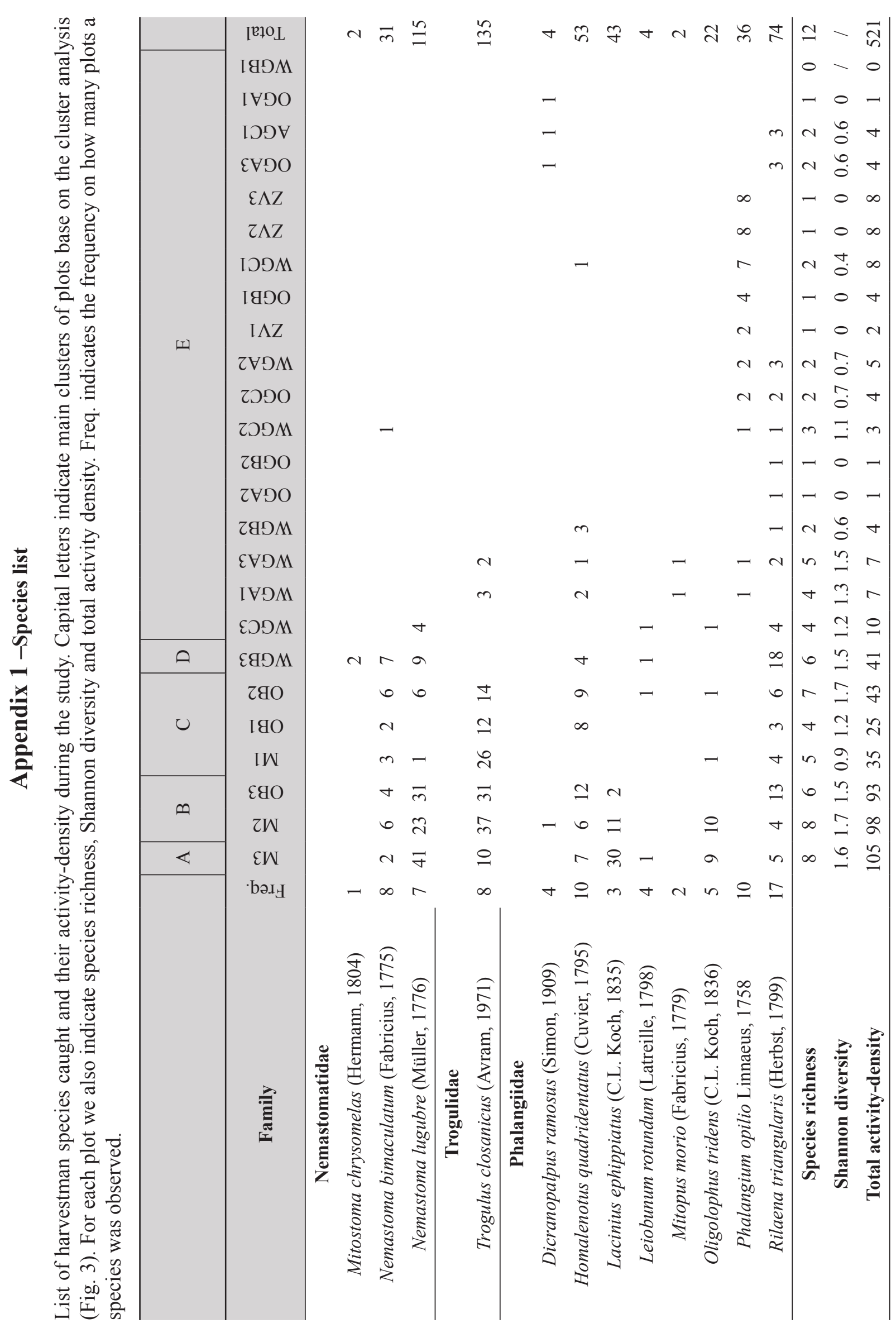




\section{Appendix 2}

Harvestman phenology in Bos van Aa and of the species represented with more than 100 individuals (Nemastoma lugubre and Trogulus closanicus). Y-axis represents the total activity-density of the species in the 25 pitfall traps.

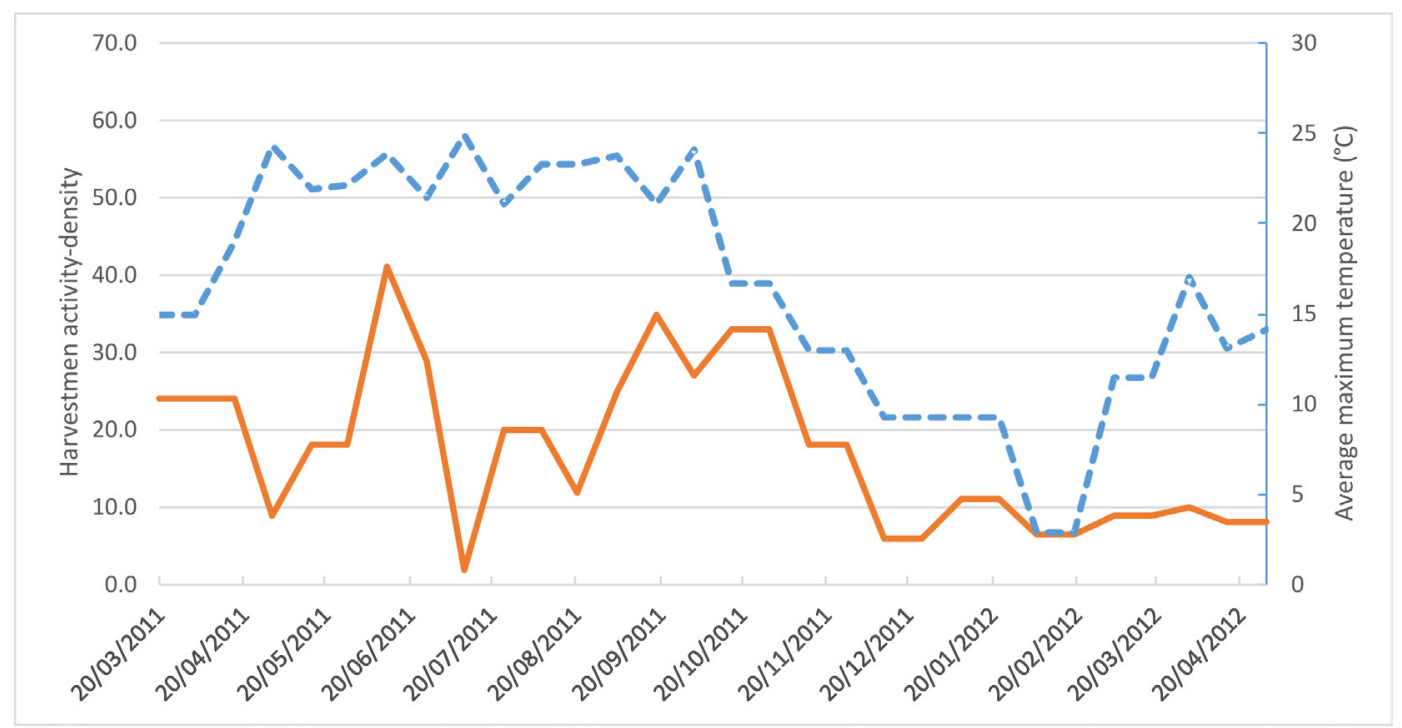

Figure A2.1 - Harvestman activity-density throughout the sampling period (solid line) and average maximum temperature (dotted line). Sample points represent the numbers caught during two weeks before the respective sampling point. In winter, traps were only emptied every four weeks. Therefore, we divided the total catch after four months in two for comparison with the other data points. Also temperature was kept constant for this two time periods in the graph.

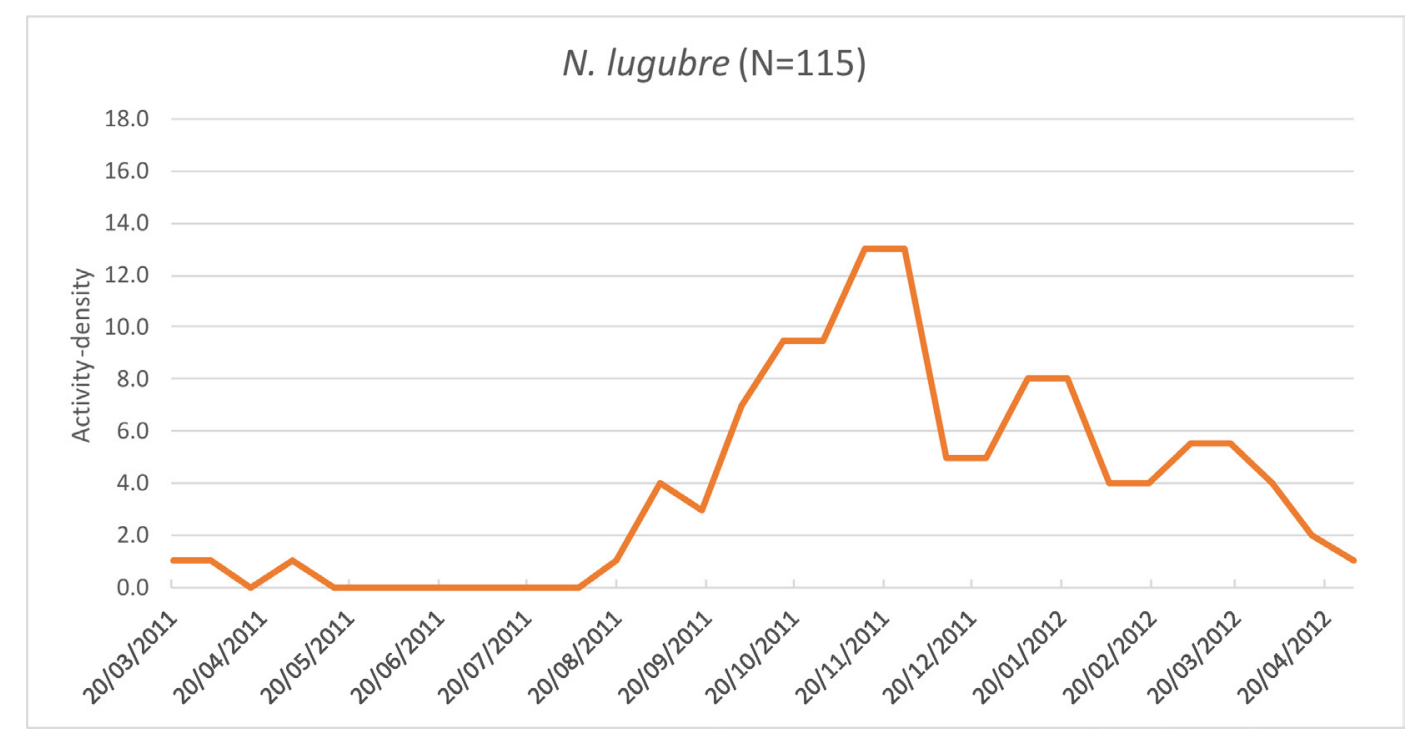

Figure A2.2 - Phenology diagram of Nemastoma lugubre. 


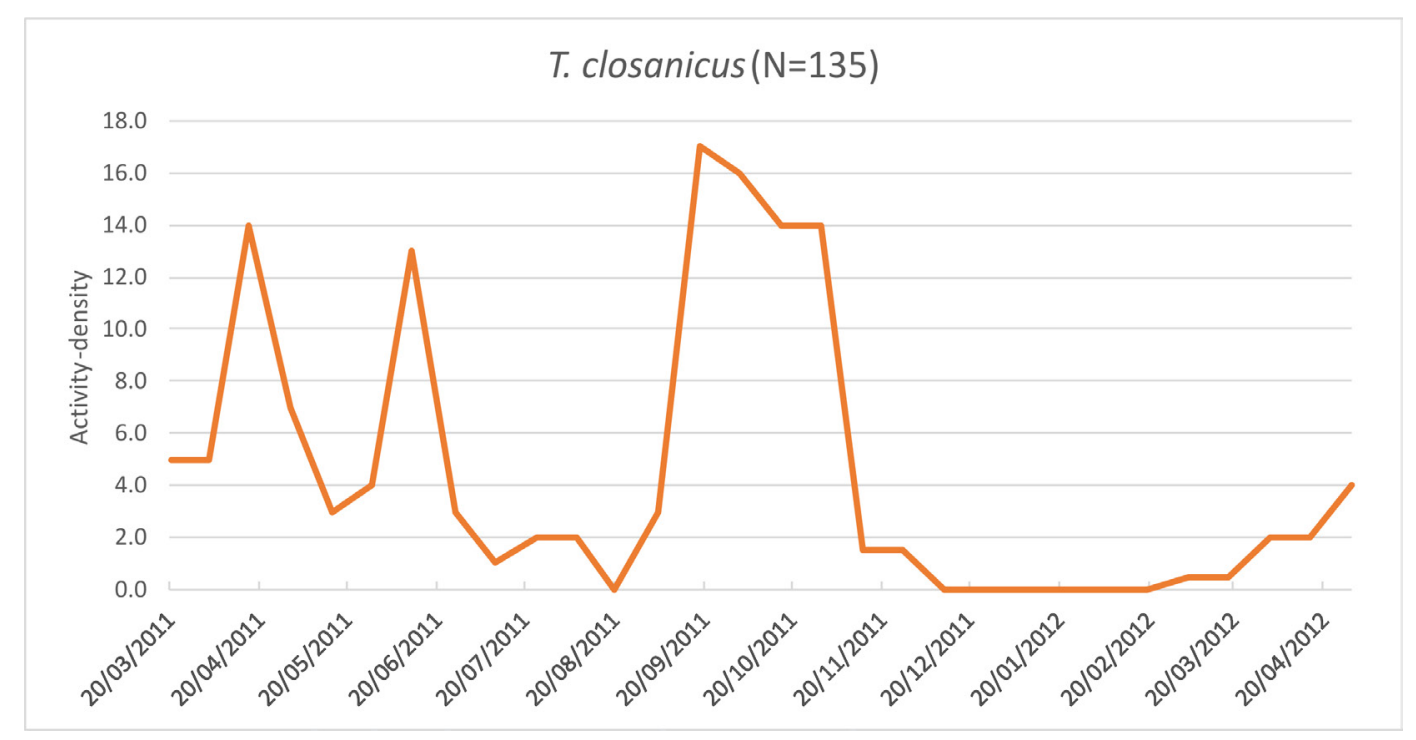

Figure A2.3 - Phenology diagram of Trogulus closanicus. 